\title{
Hubungan Indeks Massa Tubuh dengan Kadar Albumin pada Pasien Tuberkulosis Paru
}

\author{
Farina Angelia ${ }^{1}$, Deddy Herman ${ }^{2}$, Novita Ariani ${ }^{3}$ \\ ${ }^{1}$ Fakultas Kedokteran Universitas Andalas, Padang \\ ${ }^{2}$ Bagian IImu Penyakit Paru Fakultas Kedokteran Universitas Andalas/RSUP Dr. M. Djamil Padang \\ ${ }^{3}$ Bagian Radiologi Fakultas Kedokteran Universitas Andalas Padang/RSUP Dr. M. Djamil Padang
}

\section{A B S T R A C T}

Latar Belakang. Tuberkulosis (TB) paru merupakan penyakit
infeksi kronis menular yang masih membebani masyarakat
Indonesia termasuk Provinsi Sumatera Barat. Interaksi antara
infeksi dan status gizi yang buruk merupakan hal kompleks dan
saling berkaitan satu sama lain. Status gizi dapat diukur
menggunakan Indeks Massa Tubuh (IMT) dan pemeriksaan
kadar albumin.

Objektif. Mengetahui hubungan antara Indeks Massa Tubuh (IMT) dengan kadar albumin pada pasien TB paru di RSUP dr. M Djamil Padang.

Metode. Penelitian ini merupakan penelitian analitik observasional dengan pendekatan cross sectional. Data sekunder diambil dengan menggunakan rekam medik 96 pasien rawat inap TB paru RSUP dr. M. Djamil yang memenuhi kriteria inklusi dan tidak terdapat kriteria eksklusi. Data dipilih melalui purposive sampling. Variabel penelitian ialah IMT dan kadar albumin. Data yang diperoleh dimasukkan ke dalam tabel dan diolah menggunakan program SPSS. Analisis hubungan antar variabel dilakukan dengan uji chi-square.

Hasil. Hasil penelitian mendapatkan dari 96 subjek penelitian terdapat 50 orang (52.1\%) memiliki IMT kurus, 46 ornag (47.9\%) memiliki IMT normal - gemuk. Kadar albumin 96 subjek penelitian terbagi atas 23 orang (24\%) memiliki kadar albumin normal, dan 73 orang (76\%) memiliki kadar albumin rendah. Hasil analisis uji Pearson Chi-Square antara IMT dengan kadar albumin memiliki nilai p sebesar $0.017(<0.05)$.

Kesimpulan. Indeks Massa Tubuh (IMT) memiliki hubungan dengan kadar albumin pada pasien TB paru RSUP dr. M. Djamil. Kata kunci: tuberkulosis paru, indeks massa tubuh, kadar albumin.

Background. Pulmonary Tuberculosis (TB) is a contagious chronic infectious disease that still burdening the Indonesian people, including in the West Sumatera to the present. The interaction between infection and malnutrition are complex and interrelated. Nutritional status can be measured by calculating Body Mass Index (BMI) and albumin serum levels check.

Objective. To determine the relationship between Body Mass Index and albumin levels of pulmonary TB patients in M. Djamil Padang Central Public Hospital.

Method. This research was an observational analytic study with a cross-sectional approach. Secondary data retrieval using a medical record of 96 pulmonary TB patients in M. Djamil Hospital that fulfill the inclusion and exclusion criteria. The data were taken using the purposive sampling method. The research variables are Body Mass Index (BMI) and albumin levels. The data obtained is entered into a table and processed using the SPSS program. Variable relationship analysis was performed by using the chi-square test.

Result. The result of this study found that from 96 research subjects there were 50 people (52.1\%) had an underweight BMI, 46 people (47.9\%) had a normal-overweight BMI. On albumin levels, we concluded that 23 people (24\%) had normal albumin levels and the remaining 73 people (76\%) had low albumin levels. The result of the analysis with the Pearson Chi-Square test between BMI and albumin levels have a $p$ value of $0.0017(<0.05)$.

Conclusion. Body Mass Index (BMI) has a relationship with albumin levels of pulmonary TB patients M. Djamil Hospital. Keywords: pulmonary tuberculosis, body mass index, albumin levels.

\section{Apa yang sudah diketahui tentang topik ini?}

TB paru dan malnutrisi sering ditemukan bersamaan dimana status gizi kurang (malnutrisi) dapat dilihat melalui IMT dan kadar albumin yang mengalami penurunan.

\section{Apa yang ditambahkan pada studi ini?}

Terdapat adanya hubungan antara IMT dengan kadar albumin pada pasien TB paru di RSUP dr. M. Djamil Padang. IMT pasien TB yang cenderung rendah maka kadar albumin pasien juga menurun begitu pula sebaliknya, IMT yang membaik maka kadar albumin juga akan naik.

\section{CORRESPONDING AUTHOR \\ Name: Farina Angelia \\ Phone: +6281276861405 \\ E-mail: farina.angelia20@gmail.com}

\section{ARTICLE INFORMATION}

Received: September $23^{\text {rd }}, 2020$

Revised: October $15^{\text {th }}, 2020$

Available online: October $31^{\text {st }}, 2020$ 


\section{Pendahuluan}

Tuberkulosis (TB) merupakan penyakit infeksi kronik pada paru yang disebabkan oleh Mycobacterium tuberculosis. Pada umumnya proses seseorang terinfeksi oleh $M$. tuberculosis biasanya melalui inhalasi yaitu droplet nuclei (percikan dahak) pada saat batuk atau bersin, sehingga TB paru merupakan manifestasi klinis yang paling sering dibanding organ lainnya. ${ }^{1}$ Partikel kuman dapat bertahan dalam keadaan ruangan yang lembab dan gelap. Adanya ventilasi dan sinar ultraviolet yang cukup dapat mengurangi dan membunuh kuman tersebut. ${ }^{2}$

Hingga saat ini penyakit Tuberkulosis masih menjadi permasalahan masyarakat di dunia, walaupun sudah didapatkan pengobatan TB yang efektif. Sustainable Development Goal's (SDG) and WHO's End TB Strategy menegaskan akan mengakhiri epidemi TB di tahun 2030. Menurut WHO, jumlah kasus Tuberkulosis di Indonesia pada tahun 2018 adalah 570.289 kasus, berada pada urutan ketiga di bawah India (27\%) dan Cina (9\%). Dari WHO's Global Tuberculosis Report 2019 juga didapatkan di Indonesia perbandingan kasus TB wanita dan pria yaitu $37 \%: 52 \% .^{3}$

Berdasarkan Laporan Dinas Kesehatan Provinsi Sumatra Barat pada tahun 2017, angka insidensi semua tipe kasus TB sebesar 131,65 per 100.000 penduduk atau sekitar 6.852 kasus semua tipe TB. ${ }^{4}$ Dalam laporan tahunan Dinas Kesehatan Kota Padang tahun 2018, di tahun 2017 jumlah kasus TB yang terinput laporan termasuk data rumah sakit ada sebanyak 2182 kasus. Kasus TB BTA positif Kota Padang berdasarkan pemeriksaan mikroskopis mengalami penurunan dari tahun 2012 hingga tahun 2017, penemuan kasus TB lainnya cenderung meningkat. ${ }^{5}$

Tuberkulosis paru dan malnutrisi sering ditemukan secara bersamaan. Kondisi penderita TB dapat memperparah malnutirsi dengan cara mengurangi nafsu makan dan meningkatkan katabolisme dan sebaliknya, malnutrisi dapat meningkatkan perkembangan TB. Malnutrisi terjadi pada $25-40 \%$ dari pasien rawat inap dan berhubungan dengan komplikasi, tingginya morbiditas dan mortalitas pasien. Penderita dengan kenaikan berat badan yang rendah selama terapi TB berisiko untuk gagal terapi dan relaps dari penyakit TB. 6
Status nutrisi pasien dapat diukur dengan menghitung Indeks Massa Tubuh (IMT) dan memeriksa kadar albumin. Infeksi pada tuberkulosis mengakibatkan penurunan berat badan dan penyusutan tubuh. Penurunan berat badan pada pasien TB dapat dilihat dari IMT.7 Pengukuran dengan IMT memiliki kekurangan karena pada lansia yang mengalami pengurangan tinggi badan dapat memberikan hasil pengukuran yang tidak tepat. 8

Kadar albumin mengalami penurunan secara bermakna pada penderita TB. ${ }^{9}$ Penyebab penurunan kadar albumin serta protein total diduga disebabkan faktor gizi (terjadinya penurunan nafsu makan, malnutrisi, malabsorbsi) dan reaksi protein fase akut. Berdasarkan penelitian Simbolon et al (2016), didapatkan lebih banyak pasien TB yang memiliki kadar albumin $<3,5 \mathrm{~g} / \mathrm{dl}$. Hal ini disebabkan inflamasi kronis TB yang menyebabkan penurunan produksi albumin dan peningkatan penghancuran albumin sehingga terjadi hipoalbuminemia. 10,11

Albumin memiliki fungsi salah satunya sebagai transport obat-obatan ke organ target. Obat TB paru, Rifampisin dan Isoniazid memiliki ikatan yang lebih kuat dengan albumin daripada protein lain. Ikatan kuat tersebut diharapkan dapat meningkatkan efek antimikrobial dari OAT sehingga dapat menurunkan sitokin inflamasi serta mempercepat penyembuhan. ${ }^{12}$

Agar mendapatkan data dan pengetahuan yang ada mengenai hubungan IMT dengan kadar albumin pada pasien TB paru, maka kami merancang penelitian sehingga diharapkan hasil penelitian dapat cukup koklusif untuk menilai hubungan antara IMT dengan kadar albumin pada pasien TB paru di RSUP dr. M. Djamil Padang.

\section{Metode \\ Jenis penelitian yang dilakukan adalah penelitian analitik observasional dengan pendekatan cross-sectional. Populasi pada penelitian ini adalah semua pasien TB paru rawat inap di RSUP dr. M. Djamil Padang, sampel terdiri dari 96 orang pasien TB paru yang dirawat inap di RSUP dr. M. Djamil Padang dengan memenuhi kriteria inklusi dan eksklusi. Variabel pada penelitian ini adalah IMT dan kadar albumin. Data yang diperoleh, dimasukkan ke dalam tabel dan diolah menggunakan program SPSS. Analisis hubungan antar variabel dilakukan menggunakan}


uji Chi-Square. Nomor izin kaji etik dengan No. 167/KEPK/2020, dikeluarkan oleh Komite Etik Penelitian Kesehatan RSUP Dr. M. Djamil Padang.

\section{Hasil}

\section{Karakteristik Subjek Penelitian}

Karakteristik subjek penelitian ini terdiri atas jenis kelamin, usia, tingkat pendidikan, pekerjaan.

Tabel 1. Karakteristik Subjek Penelitian (n=96)

\begin{tabular}{lccc}
\hline \multicolumn{1}{c}{ Variabel } & $\begin{array}{c}\text { Frekuensi } \\
\text { (n=96) }\end{array}$ & $\begin{array}{c}\text { Persentasi } \\
\text { (\%) }\end{array}$ & $\begin{array}{c}\text { Rerata } \\
\mathbf{\pm} \text { SD }\end{array}$ \\
Jenis & & & \\
Kelamin: & 72 & 75 & \\
Laki- Laki & 24 & 25 & \\
Perempuan & & & $\mathbf{4 7 . 9 2 \pm}$ \\
Usia (tahun) & 9 & 9.4 & $\mathbf{1 6 . 6 3}$ \\
15-25 & 19 & 19.8 & \\
26-35 & 12 & 12.5 & \\
36-45 & 23 & 24.0 & \\
46-55 & 20 & 20.8 & \\
56-65 & 13 & 13.5 & \\
>65 & & & \\
Tingkat & & & \\
Pendidikan: & 20 & 20.8 & \\
SD/Sederajat & 18 & 18.8 & \\
SMP/Sederajat & 18.8 & 56.3 & \\
SMA/Sederajat & 54 & 4.2 & \\
PT/Sederajat & 4 & & \\
Pekerjaan: & & 76 & \\
Bekerja & 73 & 24 & \\
Tidak bekerja & 23 & &
\end{tabular}

Jumlah subjek penelitian mayoritas adalah laki-laki sebanyak 72 orang sedangkan perempuan sebanyak 24 orang. Rata-rata usia subjek penelitian adalah 48 tahun dengan rentang usia 20-85 tahun. Jumlah subjek penelitian didominasi oleh tamatan SMA. Penelitian mendapatkan jumlah subjek penelitian mayoritas sudah memiliki pekerjaan.

\section{Indeks Massa Tubuh}

Persebaran subjek penelitian berdasarkan indeks massa tubuh pada pasien TB paru penelitian ini terbagi atas 2, yaitu IMT kurus dan IMT normal-gemuk, dapat dilihat pada Tabel $2 \mathrm{di}$ bawah ini.

Tabel 2. Distribusi Subjek Penelitian Berdasarkan IMT

\begin{tabular}{lccc}
\hline Karakteristik & $\begin{array}{c}\text { Frekuensi } \\
(\mathbf{n = 9 6 )}\end{array}$ & $\begin{array}{c}\text { Persentasi } \\
\text { (\%) }\end{array}$ & $\begin{array}{c}\text { Rerata } \\
\mathbf{\pm} \text { SD }\end{array}$ \\
\hline IMT & & & $\mathbf{1 8 . 5 3} \pm$ \\
$\begin{array}{l}\text { Kurus } \\
\left(<18.5 \mathrm{~kg} / \mathrm{m}^{2}\right)\end{array}$ & 50 & 52.1 & $\mathbf{3 . 1 6}$ \\
$\begin{array}{l}\text { Normal-Gemuk } \\
\left(\geq 18 \mathrm{~kg} / \mathrm{m}^{2}\right)\end{array}$ & 46 & 47.9 & \\
Total & $\mathbf{9 6}$ & $\mathbf{1 0 0}$ & \\
\hline
\end{tabular}

Hasil penelitian mendapatkan rerata IMT subjek penelitian adalah $18.53 \mathrm{~kg} / \mathrm{m} 2$ (dengan rentang IMT antara $15.23-23-45 \mathrm{~kg} / \mathrm{m} 2$ ). Dari tabel diatas dapat diketahui dari 96 subjek penelitian terdapat 50 orang $(52.1 \%)$ memiliki IMT kurus, sedangkan sisanya 46 orang (47.9\%) memiliki IMT normal ke gemuk.

\section{Kadar Albumin}

Kadar albumin pada pasien TB paru penelitian ini dibagi atas 2 kategori, yaitu $\geq 3.5 \mathrm{~g} / \mathrm{dl}$ dan $<3.5$ $\mathrm{g} / \mathrm{dl}$, dapat dilihat pada Tabel 3 di bawah ini.

Tabel 3. Distribusi Subjek Penelitian dari Kadar Albumin

\begin{tabular}{lccc}
\hline Karakteristik & $\begin{array}{c}\text { Frekuensi } \\
\text { (n=96) }\end{array}$ & $\begin{array}{c}\text { Persentasi } \\
\text { (\%) }\end{array}$ & $\begin{array}{c}\text { Rerata } \pm \\
\text { SD }\end{array}$ \\
\hline Kadar & & & $\mathbf{2 . 9 0 \pm}$ \\
Albumin(g/dl) & & & $\mathbf{0 . 7 0}$ \\
$\geq 3.5 \mathrm{~g} / \mathrm{dl}$ & 23 & 24 & \\
$<3.5 \mathrm{~g} / \mathrm{dl}$ & 73 & 76 & \\
Total & $\mathbf{9 6}$ & $\mathbf{1 0 0}$ & \\
\hline
\end{tabular}

Pada tabel 3 dapat dilihat rerata kadar albumin pasien TB paru adalah $2.90 \mathrm{~g} / \mathrm{dl}$. Penelitian ini mendapatkan mayoritas dari subjek penelitian memiliki kadar albumin $<3.5 \mathrm{~g} / \mathrm{dl}$ yaitu sebanyak 73 orang, dan 23 orang sisanya memiliki kadar albumin $\geq 3.5 \mathrm{~g} / \mathrm{dl}$.

\section{Hubungan IMT dengan Kadar Albumin}

Hasil analisis bivariate antara IMT dengan kadar albumin pada pasien TB paru dapat dilihat pada Tabel 4 berikut ini.

Tabel 4. Tabulasi silang IMT dengan Kadar Albumin

\begin{tabular}{|c|c|c|c|c|}
\hline \multirow[t]{2}{*}{ IMT } & \multicolumn{2}{|c|}{ Kadar Albumin } & \multirow{2}{*}{ Total } & \multirow{2}{*}{$\begin{array}{c}\mathrm{P}- \\
\text { value }\end{array}$} \\
\hline & $\geq 3.5 \mathrm{~g} / \mathrm{dl}$ & $<3.5 \mathrm{~g} / \mathrm{dl}$ & & \\
\hline Kurus & 7 & 43 & 50 & 0.017 \\
\hline Normal- & & & & \\
\hline Gemuk & 16 & 30 & 46 & \\
\hline Total & 23 & 73 & 96 & \\
\hline
\end{tabular}

Dari tabulasi silang tersebut diatas, dapat diketahui dari 50 pasien TB paru dengan IMT kurus, terdapat sebanyak 7 orang memiliki kadar albumin $\geq 3.5 \mathrm{~g} / \mathrm{dl}$ dan 43 orang memiliki kadar albumin $<3.5 \mathrm{~g} / \mathrm{dl}$. Dari 46 orang pasien TB paru dengan IMT normal-gemuk, terdapat 16 orang memiliki $\geq 3.5 \mathrm{~g} / \mathrm{dl}$ dan 30 orang memiliki kadar albumin < 3.5 g/dl. Hasil uji Pearson Chi-Square diketahui bahwa nilai $\mathrm{p}$ value sebesar 0.017 $(<0.05)$, artinya terdapat adanya hubungan antara IMT dengan kadar albumin pada pasien TB paru. 


\section{Pembahasan}

\section{Karakteristik Subjek Penelitian}

Jumlah pasien TB paru di RSUP dr. M. Djamil didapatkan yang berjenis kelamin laki-laki sebanyak 72 orang (75\%) sedangkan dengan jenis kelamin perempuan didapatkan sebanyak 24 orang (25\%). Hasil ini menyatakan bahwa pasien TB paru dengan jenis kelamin laki-laki lebih banyak dibandingkan jenis kelamin perempuan. Hasil penelitian ini sejalan dengan penelitian Simbolon et al (2016), sebanyak 43 orang pasien TB paru di RSUP Prof. Dr. R. D. Kandou Manado, didapatkan lebih banyak laki-laki dengan jumlah 24 orang (55.81\%) dibandingkan perempuan 19 orang (44.19\%).10

Penelitian yang dilakukan Muchtar, et al. (2018) menyatakan alasan tingginya prevalensi laki-laki masih belum ada teori yang jelas, tetapi ada kemungkinan disebabkan karena mobilitas yang lebih tinggi di luar rumah pada laki-laki sehingga lebih berisiko terpapar kuman TB. ${ }^{9}$ Menurut Hiswani (2009), dikutip dari WHO penyakit ini lebih tinggi pada laki-laki dikarenakan kebiasaan merokok tembakau dan minum minuman beralkohol yang lebih banyak pada laki-laki yang dapat menyebabkan penurunan sistem imun sehingga lebih mudah terpapar agen penyebab TB paru. Berdasarkan Profil Kesehatan Indonesia (2018), jumlah kasus TB pada laki-laki lebih tinggi 1,3 kali dibandingkan pada perempuan. ${ }^{4}$

Pasien TB paru di RSUP dr. M. Djamil Padang paling banyak berada pada masa lansia awal yaitu di usia 46-55 tahun yaitu sebanyak 23 orang (24\%). Hasil ini sejalan dengan penelitian Nor Azuan (2018), menyatakan bahwa kebanyakan responden paling banyak berada pada kelompok usia 41 tahun keatas yaitu sebanyak 40.9\%.13

Penelitian yang dilakukan Simbolon et al (2016) juga menyatakan bahwa pasien yang paling banyak terkena tuberkulosis adalah pada kelompok pasien yang berusia 46-55 tahun (25.6\%). Salah satu faktor yang menyebabkan pasien TB paru mayoritas pada masa lansia awal dikarenakan sistem immunologis sudah mulai menurun sehingga rentan untuk terkena penyakit, terutama penyakit infeksi, salah satunya tuberkulosis. ${ }^{10}$

Jumlah pasien TB paru di RSUP dr. M. Djamil Padang berdasarkan tingkat pendidikan angkanya bervariasi, secara karakteristik umum mayoritas penderita TB paru merupakan lulusan SMA/Sederajat yaitu 54 orang (56.3\%). Hasil penelitian ini sama dengan penelitian yang dilakukan Eka Fitria et al (2017), menyatakan bahwa penderita TB paru terbanyak pada tamatan SMA.14 Sedangkan pada penelitian Nor Azuan (2018) menunjukkan bahwa tingkat pendidikan pada penderita TB paru terbanyak adalah tamatan PT/Sederajat yaitu 31.8\%. ${ }^{13}$

Penelitian ini bertentangan dengan penelitian yang dilakukan Pertiwi, et al (2019) dimana pasien TB paru dengan pendidikan rendah berisiko 3.11 kali lebih besar dibanding pasien TB paru dengan pendidikan tinggi. Hasil ini juga bertentangan dengan teori Notoatmojo (2012), mengatakan bahwa pendidikan berhubungan erat dengan pengetahuian sesorang, sehingga dapat diartikan tingkat pendidikan yang lebih tinggi dapat meningkatkan pengetahuan seseorang, terutama di bidang kesehatan. ${ }^{15}$

Hasil penelitian dalam jumlah pasien TB paru yang bekerja didapatkan sebanyak 73 orang (76\%) sedangkan jumlah pasien TB paru yang tidak bekerja sebanyak 23 orang (24\%). Hasil ini dapat disimpulkan mayoritas pasien TB paru di RSUP dr. M. Djamil Padang sudah bekerja. Penelitian ini sejalan dengan penelitian Nurkumalasari, et al, (2016), dimana terdapat lebih banyak pasien TB paru yang bekerja sebesar $52.2 \%{ }^{16}$

Pekerjaan dapat dilihat dari beberapa kemungkinan keterpaparan khusus dari jenis pekerjaan maupun kondisi lingkungan kerja. Faktor lingkungan kerja dapat mempengaruhi tingkat penularan suatu penyakit. Orang yang bekerja cenderung sering berinteraksi dengan orang banyak sehingga dapat mempengaruhi tingkat penularan, dimana kemungkinan terpajan oleh kuman TB lebih tinggi. ${ }^{16}$

Hasil penelitian ini juga berbeda dengan penelitian Tubalawony, et al, (2019) yang menyatakan bahwa bekerja diharapkan dapat mengurangi risiko terinfeksi TB paru. Dimana beberapa jenis pekerjaan memiliki lokasi kerja yang banyak terpapar sinar matahari, maka dari itu beberapa pekerjaan sulit untuk terpapar kuman Mycobacterium tuberculosis. Kuman tersebut mati pada suhu 100 'C selama 5-10 menit atau pada suhu $60^{\prime} \mathrm{C}$ selama 30 menit. Bakteri ini tahan selama 1-2 jam diudara terutama ditempat 
yang lembab dan gelap, namun tidak tahan akan sinar matahari atau aliran udara. ${ }^{17}$

\section{Indeks Massa Tubuh}

Hasil distribusi data IMT dari pasien TB paru di RSUP dr. M. Djamil Padang menunjukkan bahwa pasien TB paru paling banyak memiliki IMT $<18.5$ $\mathrm{kg} / \mathrm{m}^{2}$ (kurus) yaitu sebanyak 50 orang $(52.1 \%)$. Hasil penelitian ini sejalan dengan penelitian yang dilakukan oleh Putri, et al, (2016) dimana mendapatkan pasien TB paru paling banyak dengan IMT yang tergolong underweight $(<18.5$ $\mathrm{kg} / \mathrm{m}^{2}$ ) sebesar $61,1 \% .18$

Penelitian ini sejalan dengan penelitian Nalabothu, et al, (2014) di Siddharta Medical College, India, dimana dari 50 keseluruhan subjek penelitian, terdapat 33 pasien (66\%) memiliki IMT yang rendah $\left(<18.5 \mathrm{~kg} / \mathrm{m}^{2}\right) .{ }^{11}$ Sedangkan pada penelitian Tama, et al, (2016), dari 120 pasien subjek penelitian, didapatkan jumlah yang sama antara IMT tergolong underweight dengan IMT yang tergolong normal yaitu 60:60.19

Body wasting, meliputi IMT yang cenderung menurun merupakan ciri khas dari pasien TB. Wasting menyebabkan terjadinya gangguan pada fungsi tubuh, dan apabila dibiarkan akan menyebabkan kematian pada pasien TB. Pasien TB dapat mengalami wasting selama berbulanbulan, bahkan saat pasien sudah memulai menjalani terapi OAT. Sehingga daapt dinyatakan bahwa gizi kurang meningkatkan risiko perkembangan infeksi TB dan meningkatkan risiko kematian. ${ }^{20}$

Status gizi dapat diukur berdasarkan Indeks Massa Tubuh/IMT. Kondisi IMT yang rendah atau gizi yang kurang berhubungan dengan perburukan tubuh dan menjadi faktor risiko utama terhadap morbiditas dan mortalitas pada penyakit TB. Berdasarkan penelitian M. Naseer et al (2015), menyatakan bahwa 34.6\% subjek yang mengalami risiko gizi kurang selama 7 tahun follow-up meninggal akibat gizi kurang. Penelitian tersebut juga menjelaskan bahwa angka harapan hidup pada pasien gizi kurang itu sangat rendah $18.7 \%{ }^{21}$

\section{Kadar Albumin}

Hasil penelitian menyatakan dari 96 orang pasien terdapat sebanyak 73 orang (76\%) pasien memiliki kadar albumin $<3.5 \mathrm{~g} / \mathrm{dl}$ sedangkan 23 orang $(24 \%)$ sisanya memiliki kadar albumin $\geq$
$3.5 \mathrm{~g} / \mathrm{dl}$. Hasil ini menunjukkan bahwa lebih banyak pasien TB paru di RSUP dr. M. Djamil Padang yang memiliki kadar albumin $<3.5 \mathrm{~g} / \mathrm{dl}$. Hasil penelitian ini sejalan dengan penelitian Anggraeni, et al (2019), yang menyatakan bahwa dari 40 total sampel, terdapat 35 orang (88\%) pasien TB yang memiliki kadar albumin rendah. ${ }^{22}$

Penelitian ini sejalan dengan penelitian yang dilakukan Simbolon, et al, (2016) dimana dari 43 orang sampel didapatkan 30 orang diantaranya memiliki kadar albumin $<3.5 \mathrm{~g} / \mathrm{dl}$. Hal ini disebabkan pada proses inflamasi pada tuberkulosis mengakibatkan penurunan produksi dan peningkatan penghancuran albumin sehingga terjadi kekurangan albumin di dalam darah. ${ }^{10}$

Fungsi albumin salah satunya adalah sebagai protein pengikat atau sebagai carrier OAT (Rifampisin dan Isoniazid) hingga menuju target kerja obat. Penurunan kadar albumin dapat menyebabkan transport OAT menuju organ target menjadi terganggu khususnya obat pada fase intensif. Terganggunya daya kerja OAT ini akan memperlambat proses pembunuhan bakteri dan pemulihan jaringan paru yang rusak. Keadaan ini dapat menyebabkan tingginya mortalitas, meningkatnya resiko kekambuhan dan kejadian hepatitis OAT. ${ }^{12}$

Penelitian yang dilakukan Wijaya GK et al (2015) menyatakan bahwa adanya peningkatan albumin terhadap pemberian protein sebagai pendamping terapi TB. Hal ini akan menyebabkan penurunan dari laju degradasi albumin dan peningkatan dari sintesis albumin. Peningkatan kadar albumin dapat meningkatkan efektifitas kerja OAT sehingga berefek pada pengobatan TB yang efektif. ${ }^{23}$

Mega, et al (2019) mendapatkan hasil penelitian yang berbeda yaitu, dari 39 keseluruhan sampel terdapat 25 orang (64.1\%) pasien TB yang memiliki kadar albumin rendah $(\geq$ $3.5 \mathrm{~g} / \mathrm{dl}$ ). Terjadinya perbedaan hasil penelitian dikarenakan adanya perbedaan populasi yang digunakan dimana pasien yang mempunyai kadar albumin $\geq 3.5 \mathrm{~g} / \mathrm{dl}$ masih berada pada stadium awal penyakit tuberkulosis. ${ }^{24}$

\section{Hubungan IMT dengan Kadar Albumin}

Hasil penelitian ini yang dilakukan dengan uji Pearson Chi-Square memperoleh nilai $\mathrm{p}$ value sebesar $0.017 \quad(<0.05)$ sehingga dapat disimpulkan terdapat adanya hubungan antara 
kadar albumin dengan IMT pada pasien TB paru. Kesimpulannya adalah setiap IMT mengalami penurunan maka kadar albumin akan mengalami penurunan dan begitu pula sebaliknya. Serupa dengan penelitian yang dilakukan Mega, et al (2019) yang menyatakan bahwa terdapat hubungan signifikan antara indeks massa tubuh dengan kadar albumin. Hal ini menggambarkan bahwa IMT dapat mempengaruhi kadar albumin dan begitu pun sebaliknya. ${ }^{24}$

Simbolon et al (2016) juga menemukan bahwa terdapat hubungan antara indeks massa tubuh dengan kadar albumin yang memiliki arti setiap penurunan IMT maka terjadi penurunan kadar albumin. ${ }^{10}$ Banyak penelitian yang melaporkan kadar albumin serum yang rendah ( $<3.5 \mathrm{~g} / \mathrm{dl}$ ) yang merupakan indikator status protein pada saat diagnosis TB aktif. Ciri khas dari pasien TB paru yaitu mengalami Body wasting, meliputi penurunan pada IMT.25 Studi yang dilakukan Malawi menemukan bahwa rendahnya IMT pasien berhubungan dengan tingkat keparahan penyakit TB. Hal ini membuat proses penyembuhan menjadi terhambat. ${ }^{19}$

Albumin merupakan protein fase akut negatif menurun saat infeksi, luka, atau stress. ${ }^{12}$ Pada saat terjadinya infeksi TB paru, diaktifkannya Cell mediated Immunity yang mengaktifkan makrofag dan sel limfosit $T$. Sel $T$ dan makrofag memproduksi sitokin pro-inflamasi dan bila berlebihan secara umum dapat merusak. Sitokin selama respon protein fase akut, mengatur kadar albumin serum. Peningkatan produksi sitokin menyebabkan penarikan albumin dari intravaskuler ke dalam sel hati dan akan kembali jika proses inflamasi selesai. ${ }^{26}$

Beberapa penelitian menyatakan bahwa malnutrisi dan hipoalbuminemia sering ditemukan pada pasien rawat inap baik dalam kondisi akut maupun kronis. Sehingga IMT dan kadar albumin dapat dijadikan indikator prognosis yang penting. Rendahnya kadar albumin dan juga IMT sering dihubungan dengan peningkatan angka morbiditas dan mortalitas. ${ }^{27}$

Pasien dalam masa pengobatan dapat dianjurkan terapi pendamping TB yaitu, berupa asupan makanan yang kaya protein serta kalori yang cukup agar dapat mencegah kerusakan jaringan dan membantu penyembuhan. Makanan yang dianjurkan dapat berupa telur, daging rendah lemak, susu, buah, dan sayuran. Dengan asupan gizi yang cukup sangat berpengaruh dalam kenaikan IMT dan juga kadar albumin. ${ }^{28}$

\section{Simpulan}

Subjek penelitian yang diperoleh mayoritas berjenis kelamin laki-laki dengan kategori terbanyak pada usia lansia awal yaitu 46-55 tahun, dari segi pendidikan terbanyak merupakan lulusan SMA, dan subjek didominasi oleh pasien yang sudah memiliki pekerjaan. Pasien TB paru rawat inap di RSUP Dr. M. Djamil Padang mayoritas memiliki IMT yang kurus, serta terbanyak memiliki kadar albumin yang rendah. Pada hasil dapat disimpulkan bahwa terdapat hubungan yang bermakna antara IMT dengan kadar albumin pada pasien TB paru di RSUP Dr. M. Djamil Padang.

\section{Ucapan Terima Kasih}

Ucapan terima kasih disampaikan kepada semua pihak yang telah berperan mendukung penelitian ini.

\section{Daftar Pustaka}

1. Hasan H. Buku Ajar Ilmu Penyakit Paru. Wibisono MJ, Winariani HS, editor. Jakarta: Dept. Ilmu Penyakit Paru FK Unair; 2010.h.9-16.

2. Amin Z BA. Tuberkulosis Paru. In: Sudoyo AW, Setiyohadi B, Alwi I, Simadibrata M SS, editor. Buku Ajar Ilmu Penyakit Dalam. 2nd ed. Jakarta: Interna Publishing; 2009.h.1825-9.

3. World Health Organization. Global Tuberculosis Report 2019[internet]. 2019. [cited 30 Januari 2020]. Available www.who.int/tb/publications/global_report.

4. Profil Kesehatan Indonesia 2018 [Internet]. 2019. [ cited 2 Februari 2020] Available from: http://www.depkes.go.id/resources/download/pus datin/profil-kesehatan-indonesia/Data-danInformasi_Profil-Kesehatan-Indonesia-2018.pdf

5. Dinas Kesehatan Kota Padang. Pencegahan dan Pengendalian Penyakit Menular. In: Laporan Tahunan 2018. Padang; 2019.h.135-6.

6. Nasution. Malnutrisi dan Anemia pada Penderita Tuberkulosis Paru. Majority. 2015;4(8):29-35.

7. Slamet. Hubungan Kadar Albumin pada Penderita Penyakit Tuberkulosis Paru Selama Masa Pengobatan di Unit Pengobatan Penyakit Paru - Paru Pontianak. Anal Kesehat Poltekkes Kemenkes Pontianak. 2016;8(3):375-7.

8. Putri WA, Munir SM CE. Gambaran Status Gizi pada Pasien Tuberkulosis Paru (TB Paru) yang Menjalani Rawat Inap di RSUD Arifin Achmad Pekanbaru. J Online Mhs Fak Kedokt Univ Riau. 2016;3(2):1-16.

9. Muchtar NH, Herman D Y. Gambaran Faktor Risiko Timbulnya Tuberkulosis Paru pada Pasien yang Berkunjung ke Unit DOTS RSUP Dr . M . Djamil. J Fak Kedokt Unand. 2018;7(1):80-7.

10. Simbolon HT, Lombo JC WM. Hubungan indeks massa tubuh dengan kadar albumin pada pasien 
tuberkulosis paru. J e-Clinic. 2016;4(2):2-6.

11. Nalabothu SK, K SMK. Role of serum albumin in monitoring nutritional status in patients with pulmonary tuberculosis. Asian Pacific J Heal Sci. 2014;1(4):486-91.

12. Prastowo A, Lestariana $W$, Nurdjanah $S$, Sutomo R, Kedokteran F, Jenderal U, et al. Efektifitas Pemberian Ekstra Putih Telur terhadap Peningkatan Kadar Albumin dan IL-6 pada Pasien Tuberkulosis dengan Hipoalbumin. J Kesehat. 2016;1(1):10-8.

13. Azuan N. Gambaran IMT pada Pasien TB paru di Poliklinik Paru di RSUP dr. M. Djamil Padang[skripsi]. Padang : Universitas Andalas; 2018.

14. Fitria E, Ramadhan R. Karakteristik Penderita Tuberkulosis Paru di Puskesmas Rujukan Mikroskopis Kabupaten Aceh Besar. J Penelit Kesehat. 2017;4(1):13-20.

15. Pertiwi J, Ratnaningrum D, Veteran U, Nusantara B, Veteran U, Nusantara B, et al. Analisis Faktor Risiko Tuberkulosis Paru Dewasa di Kabupaten Sukoharjo. Semin Nas Univ Tunas Pembang Surakarta. 2019;(April):277-87.

16. Nurkumalasari, Wahyuni D NN. Hubungan Karakteristik Penderita Tuberkulosis Paru dengan Hasil Pemeriksaan Dahak di Kabupaten Ogan Ilir. J Keperawatan Sriwij. 2016;3(2):51-8.

17. Tubalawony SL MS. Faktor yang Berhubungan dengan kejadian TB Paru Dewasa pada Penderita Rawat jalan RSUD Tulehu. Moluccas Heal J. 2019;1(3):50-6.

18. Putri, Wina A, Munir, Sri M, Christianto E. Gambaran Status Gizi pada Pasien Tuberkulosis Paru yang Menjalani Rawat Inap di RSUD Arifin Achmad Pekanbaru. J Online Mhs Fak Kedokt Univ Riau. 2016;3(2):1-16.

19. Dwi T, Adisasmita AC, Burhan E. Indeks Massa Tubuh dan Waktu Terjadinya Konversi Sputum pada Pasien Tuberkulosis Paru BTA Positif di RSUP Persahabatan Tahun 2012. J Epidemiol Kesehat Indones. 2016;1(1):1-8.

20. Salsabela FE, Suryadinata H DI. Gambaran Status Nutrisi pada Pasien Tuberkulosis di Rumah Sakit Umum Pusat Hasan Sadikin Bandung. J Sains dan Kesehat. 2016;2(2):81-9.

21. Naseer M, Forssell H FC. Malnutrition, Functional Ability and Mortality among Older People Aged $>60$ Years: a 7-Years Longitudinal Study. Eur J Clin Nutr. 2016;70(3):399-404.

22. Anggraeni DN SN. Pengaruh Persentase Kadar Albumin Terhadap Malnutrisi pada Penderita Tuberkulosis. Pros Semin Nas. 2019;4:355-9.

23. Wijaya G. Pengaruh Kapsul Ekstrak Ikan Gabus Terhadap Kadar Albumin pada Pasien Tuberkulosis Paru Pengobatan Fase Intensif[tesis]. Jember:Universitas Jember. 2015.

24. Mega JY, Sari DK HJ. Korelasi Indeks Massa Tubuh dan Kadar Albumin dengan Konversi Sputum Pasien Tuberkulosis. Indones J Hum Nutr. 2019;13:96-109.

25. Pratomo IP, Burhan E T V. Malnutrisi dan Tuberkulosis. J Indones Med Assoc. 2012;62(June):230-7.

26. Sri Rejeki NMDP, Kuswardhani RAT. Korelasi albumin serum dan interleukin-6 (IL-6) serum pada pasien geriatri di RSUP Sanglah Denpasar Bali Indonesia. Medicina (B Aires). 2019;50(2):396-9.

27. Campbell SE, Avenell A WA. Assessment of Nutritional Status in Hospital In-patients. QJM. 95(2):83-7.
28. Sahare E, Sartini NM. Hubungan IMT terhadap kadar Hemoglobin pada Paien TB Paru di RSU Sultan Sulaiman Kab. Serdang Bedagai. BioLink. 2015;2(1):10-5. 